\title{
Are Emerging Market Economies Subject to Credit Rating Bias?: Evidence from South Africa, Hungary and Turkey Cases
}

\author{
Bilge CANBALOĞLU iDa Özge SEZGIN ALP iDb Güray KÜÇÜKKOCAOĞLU iDc \\ a Ankara Yıldırım Beyazıt University, Business School, Department of International Trade and Business, Ankara, Turkey \\ bbakin@ybu.edu.tr \\ ${ }^{b}$ Baskent University, Faculty of Commercial Sciences, Accounting and Financial Management Department, Ankara, Turkey \\ osezgin@baskent.edu.tr \\ ${ }^{\mathrm{c}}$ Başkent University, Faculty of Economics and Administrative Sciences, Department of Management, Ankara, Turkey \\ gurayk@baskent.edu.tr
}

\begin{tabular}{|c|c|}
\hline ARTICLE INFO & ABSTRACT \\
\hline Keywords: & Purpose - This study aims to reveal whether there exists bias in the assignments of S\&P and \\
\hline $\begin{array}{l}\text { Credit Rating Agencies } \\
\text { Sovereign Ratings }\end{array}$ & $\begin{array}{l}\text { Moody's specifically against South Africa, Hungary and Turkey by also exploring the } \\
\text { determinants of credit ratings of these three countries for the time span of } 2002: \mathrm{Q} 4-2016: \mathrm{Q} 4 \text {. }\end{array}$ \\
\hline Emerging Market Economies & Design/methodology/approach - The independent t-test and one-way ANOVA test are utilized \\
\hline Received 1 April 2019 & $\begin{array}{l}\text { when the means of S\&P and Moody's grades of three countries are compared. Besides, in order } \\
\text { to inspect how the macroeconomic determinants of the credit ratings of each country affect }\end{array}$ \\
\hline Revised 30 May 2019 & their credit ratings and detect the subjectivity component of the country rating models, OLS \\
\hline Accepted 18 May 2019 & $\begin{array}{l}\text { regresion models are constructed. Finally, pooled regression model including country dummy } \\
\text { variables is established to detect whether countries are initially rated with a bias by the Credit }\end{array}$ \\
\hline $\begin{array}{l}\text { Article Classification: } \\
\text { Research Article }\end{array}$ & $\begin{array}{l}\text { variables is established to detect whether countries are ini } \\
\text { Rating Agencies (CRAs) regardless of economic variables. }\end{array}$ \\
\hline
\end{tabular}

Research Article

\begin{abstract}
Empirical Results: First, the mean comparison tests show that Turkey has the least credit ratings among the three by both S\&P and Moody's, and the difference between the means are statistically significant. Secondly, the OLS regressions' results show that the macroeconomic determinants of sovereign ratings are not definite for all countries as specified in the previous studies. The ratings of each country are influenced by different variables with different significance. Furthermore, the subjective component of the OLS model (the part cannot be explained by the economic variables) in Hungary is smaller when compared to the subjective components of South Africa's and Turkey's models, which indicates that the changes in credit ratings is explained by the economic variables mostly in Hungary. Finally, the pooled regression results denote that Turkey is assigned with the least grades without considering the macroeconomic indicators when compared to South Africa and Hungary.
\end{abstract}

Discussion: Though it is maintained that the credit ratings of the sovereigns are mostly determined by their economic indicators, this study shows that these three emerging market economies are not evaluated transparently and fairly by the CRAs. Even if they are classified under emerging market economies, Turkey is assigned by the lowest grades when compared to others. This can be linked with the possibility of intense relations of South Africa and Hungary with advanced economies.

\section{Introduction}

Although the credit rating agencies (CRAs) have gathered considerable attention with the improvements of financial globalization, their existence dates back over a century. The CRAs point out their opinion as credit ratings about the creditworthiness of a company, country or security for a specific date. Hence, the sovereign ratings assigned by the CRAs provide information to the market players about the borrowers and investments, which tries to minimize information asymmetry in the financial markets (US SEC, 2004). In essence, the sovereign credit ratings are crucial measures for determining the cost of borrowing. The changes 


\section{B. Canbaloğlu - Ö. S. Alp - G. Küçükkocaoğlu 11/2 (2019) 1068-1078}

in these ratings have an effect on the terms of borrowing available to a country (Iyengar, 2012). A better sovereign rating also cause the advantage of having lower sovereign bond spread (Doluca, 2014). Besides, the CRAs have considerable impact on the terms on which developing countries can tap international capital markets. In addition, when the sovereign debt ratings are downgraded speculatively there are costly implications for national governments. (Tennant and Tracey, 2016). However, though the sovereign credit ratings are so vital for the countries due to these reasons, the ratings assigned by the CRAs have been frequently criticized for being unreliable and non-transparent.

The financial markets are dominated by three prominent agencies called Moody's Investors Service Inc. (Moody's), Fitch Inc. (Fitch), and the Standard and Poor's Division of the McGraw-Hill Companies Inc. $(\mathrm{S} \& \mathrm{P})$. These agencies form committees to assign ratings to the debt issuers; however, the procedures in the rating assignments are not always straightforward. The processes used by the agencies consist of not only the quantitative methods, but also qualitative ones, and the CRAs offer little information about the assigned weights of the factors (Elkhoury, 2008). Moreover, these factor weights can vary internationally and domestically. Furthermore, they are not fully transparent in their disclosure of the methodology used for assigning a credit rating to a sovereign (Luitel et al., 2016). Hence, this leads to highly judgmental decisions in the committees and the view that the decisions of the agencies could include some bias.

As the significance of sovereign ratings and the criticism for the assesment process of the CRAs have mounted, some researchers strive to reveal the determinants of the sovereign credit ratings in order to shed light on the decision mechanism of the CRAs (Cantor and Packer, 1996; Hu et al., 2002; Mellios and PagetBlanc, 2006; Gaillard, 2009; etc.). On the other hand, some studies concentrates on whether the gradings of CRAs involve bias or not. Based on previous literature, three different type of sovereign rating bias is summarized as in Luitel et al., (2016): (1) the rating agencies assign a higher rating to their home country which corresponds to a home country bias (Fuchs and Gerry, 2017), (2) the rating agencies assign a higher rating to countries that are close to them which corresponds to a proximity bias (Doluca, 2014), and (3) the rating agencies underrate emerging / developing countries when compared to advanced economies (Tennat and Tracey, 2016; Kucuksarac and Duran, 2016). Particularly, as in the case of third type of bias when the emerging or developing countries are underrated, their costs of borrowing rise significantly and they encounter more difficulties in the international financial markets in terms of the availability of funds. Hence, this leads to hamper their economic development in the long run.

As discussed in the existing literature, the determinants of sovereign credit ratings are not distinct, and the decisions of the CRAs may involve home country, proximity or developing/emrging country bias, which in turn destroys reliability of CRAs. Therefore, the criticism are building against the CRAs in terms of their sovereign gradings in the recent years. In this context, this study explores whether there exists bias in the assignments of S\&P and Moody's specifically against Hungary, South Africa and Turkey by scrutinizing the determinants of credit ratings of these three countries over the time period of 2002:Q4 - 2016:Q4. These countries are particularly selected since they are deemed as outstanding emerging market economies from different continents, and offer lucrative investment opportunities with their high growing potentials. However, even if these are grouped under the same category, particularly South Africa and Hungary have strong ties with the advanced economies, which, in turn, may affect the creditworthiness of these countries positively in the assessments of CRAs. For instance, South Africa and Britain have strong affairs in various fields. As it is maintained in the speech of William Hauge (i.e. foreign secretary of Britain in 2012) that the history between Britain and South Africa dates back to 1795, and Britain supports South Africa in many areas. To illlustrate, Britain both reinforces the health and social improvements in South Africa and promotes its voice in the world affairs. Moreover, he claims that Britain is the fifth largest trading partner of South Africa and the only single largest country bringing foreign direct investments in South Africa. In addition to these, British government reinforces the small and medium sized businesses in South Africa to offer more job opportunties with the help of UK / South Africa Entreprenuers Program (GOV. UK, 2012). Thus, having such a support from one of the world's strongest economies may provide many advantages to South Africa when it is rated by the CRAs. In similar vein, Hungary has intense relations with European Union (EU) due to its membership of EU since 2004. Being a member of EU, Hungary has received so many benefits from strengthened cooperation contributing to achievement of economic, social and territorial cohesion. However, the benefits in the finance and economic fields are quite remarkable. All EU member 


\section{B. Canbaloğlu - Ö. S. Alp - G. Küçükkocaoğlu 11/2 (2019) 1068-1078}

countries are part of economic and monetary union (EMU) offering an economic cooperation framework to stimulate job creation and maintain sustainable growth, as well as to provide support against global economic and financial difficulties. As experienced in 2008 Global Financial Crisis, when the financial and economic crisis break out, the EU Commission, the European Central Bank (ECB) and the national governments cooperate to efface the difficulties in the economy by restoring the financial stability, promoting growth and job opportunities, and reinforcing banking system. All these measures are conducted to protect the financial stability in EU and resolve the tension in the sovereign debt markets in the euro area (European Union, 2018). Therefore, as being a part of EU, Hungary can benefit from the protection of EU when it is graded by credit rating agencies. On the other hand, when compared to South Africa and Hungary, Turkey neither has concrete connections with the advanced economies nor is supported by strong economies apparently. Therefore, absence of economic ties with strong supporters leaves Turkey more vulnerable during the times of crisis, which can be regarded as negatively by the CRAs. In the light of these, this study reveals whether these countries are also exposed to bias within their emerging and developing country group. As for methodology, various statistical techniques such as mean comparison tests, one-way ANOVA, ordinary least square and pooled regressions are utilized for the empirical analyses.

The study is organized by focusing on literature review in Section 2 . Section 3 presents the data, methodology and empirical test results. Section 4 concludes and discusses the study.

\section{Literature Review}

The study of Cantor and Packer (1996) leads the literature regarding the determinants of sovereign credit ratings, uses 49 countries to detect the factors that are significant for the credit ratings of the countries assigned by S\&P and Moody's. They transform the credit ratings of both rating agencies into numerical form and test the impact of per capita income, GDP growth, inflation, fiscal balance, external balance, external debt, economic development and default history on the country's ratings by employing ordinary least square (OLS) method. They reveal that per capita income, GDP growth, external debt, inflation, level of economic development and default history are significant determinants of sovereign ratings. Their study offers evidence on the intense correlation between macroeconomic indicators and sovereign ratings. Haque et al. (1996) handle the creditworthiness of countries by considering three variables, namely; institutional investor, euromoney and the economist intelligence unit. These variables are selected to gauge the capacity of countries to fulfill its financial obligations. They figure out what affects the credit ratings of 60 countries mostly using regression analysis. As their empirical findings suggest, the economic indicators explain considerably the variation of the developing countries' creditworthiness. In particular, the ratio of nongold foreign exchange reserves to imports, the current account balance of GDP ratio, the growth rate and the inflation influence the country' s ratings significantly. Moreover, Larrain et al. (1997) also examine the causality between country ratings and yield spreads on government bonds of 26 emerging market economies for the time span of 1988-1995 by considering a set of macroeconomic variables including foreign debt, government spending, inflation, current account deficit, real GDP growth rate, savings and default history. According to their Granger causality test results, they reveal that the dollar bond yield spreads and the given set of macroeconomic variables account for the variation of the credit ratings better.

Furthermore, Hu et al. (2002) study a broad set of countries over the period of 1981-1998, using a probit model and suggest that country's default history, a smaller amount of reserves, higher indebtness, higher inflation and a country's situation about industrialization lead to lower credit ratings. Additionally, Mellios and Paget-Blanc (2006) scrutinize the factors influencing the sovereign credit ratings by examining 86 countries for the time line between 1998 and 2002. They apply principal component analysis to determine mutual factors that have an impact on the sovereign ratings, and these variables are put in the ordered logistic model to observe their impacts on the ratings. The empirical results offer that per capita income, inflation, real exchange rate changes, government income and past default are most significant factors in the ratings. Moreover, the results also indicate that the corruption index is significant in the determination of ratings.

Gaillard (2009) considers the ratings of 105 non-US local and regional government entities utilizing an ordered probit model to explore the relationship between ratings of these entities and a group of economic and financial variables. The empirical findings offer that $80 \%$ of the variation in the ratings of the sovereign 
issuer is explained by sovereign issuer's default history, per capita income and the ratio of local government's net debt to operating revenue. In the same vein, Kabadayi and Celik (2015) investigate the determinants of the 19 emerging countries' sovereign credit ratings for the time span from 1993 and 2009 by implementing probit and logit panel data methods. Their findings imply that external debt, inflation, current account deficit and real exchange rate affect the ratings of emerging countries in a negative and significant way, whereas GDP per capita, domestic savings and index obtained from Heritage Foundation have positive and significant impacts on the sovereign ratings of these countries.

The study of Vernazza and Nielsen (2015) provide empirical analysis about the sovereign credit ratings from slightly different perspective. As they investigate sovereign ratings of advanced and emerging economies for the time period of 1996 - 2013, they separate factors influencing the sovereign ratings assigned by three major rating agencies (i.e. S\&P, Moody's and Fitch) into two parts as an objective component and a subjective component. The objective component consists of ten explanatory variables including real GDP, real per capita income, current account balance, external debt, past default, country's development level and the indices of government and rule of law. The subjective part, retrieved by the residual component of OLS regression, cannot be explained by the objective part and represents the bias in the ratings. Their main finding is that objective factor can be evaluated in the default predictions for both the short and long run, while the subjective component does not have any explanatory power on default predictions of one or more. Another significant result is that the subjective components offer biased default forecasts with adverse outcomes particularly for the likelihood of default within 3 years.

There also exist studies investigating the types of subjectivity involved in the decisions of the CRAs. Firstly, Fuchs and Gering (2017) estimate the determinants of sovereign ratings to test whether the agencies assign higher ratings to their respective home countries, as well as to economically, geopolitically, and culturally aligned countries. Their results show the advantage of home country.

Secondly, Doluca (2014) uses the variables proxying the interconnection between the country in which the rating agency is headquartered and the rated country. It is argued that the home country bias is ambiguous however, there may be a bias for interconnected countries. The results indicate that the interconnection of the US with the rated country proxied by the trade channel does not imply any home country bias but based on the interconnection between US financial institutions and the respective countries indicate a bias with respect to the ratings from Moody's only.

Thirdly, Tennat and Tracey (2016) indicated that CRA's find it more difficult to upgrade poor countries relative to rich countries, for any given improvement in ability and willingness to repay debts. This bias intuition is supported with the model results investigating the economic and institutional determinants of sovereign debt ratings. In the same vein, Kucuksarac and Duran (2016) explore the determinants of credit ratings of both developed (16) and emerging (13) countries to determine the existence of negative bias towards emerging ones by the credit rating agencies using pooled panel regression. The empirical results offer that even if developed and emerging economies have similar macroeconomic factors, the emerging economies are assigned 1.4 steps lower sovereign rating when compared to the developed countries. This study also offer findings in terms of the determinants of CRAs' grading decision. The sovereign ratings of developed countries are mostly determined by GDP growth, public debt, GDP and inflation volatility; whereas the ratings of emerging economies are mostly affected by GPD per capita, government debt, inflation and financial depth.

\section{Methodological Framework and Empirical Results}

This study regards the sovereign credit ratings of Hungary, South Africa and Turkey graded by S\&P and Moody's over the period of 2002:Q4 - 2016:Q4. S\&P grades the creditworthiness of sovereigns and various investments in the scale ranging between AAA (highest investment grade) and D (lowest grade-i.e. default) (S\&P, 2016). On the other hand, Moody's investment grades lie between Aaa (highest grade) and C (lowest grade- default with little possibility of recovery) (Moody's Investor Service, 2017). The ordinal scale of investment grades of both agencies for Turkey, Hungary and South Africa are transformed into numeric variables by scoring the highest grade as 63 and the lowest grade as $0^{1}$. This numeric transformation is

\footnotetext{
${ }^{1}$ The data of credit rating of three countries are retrieved from https://tr.tradingeconomics.com/country-list/rating To save space, the table including the numerical transformation of the grades are available upon request.
} 
B. Canbaloğlu - Ö. S. Alp - G. Küçükkocaoğlu 11/2 (2019) 1068-1078

slightly different from the grade transformation applied by Cantor and Pecker (1996), Mellios and PagetBlanc (2006) etc. Besides the investment grade, the judgments of S\&P and Moody's about the outlook of investment (i.e. positive, stable and negative) are also regarded since the agencies do not alter the grade but they can upgrade or downgrade the outlook of the investment in some cases. Hence, this numeric transformation can offer better results since it takes into account the investment outlook judgments. The descriptive statistics of their ratings are presented in Table 1. As observed, South Africa has been assigned with the highest grade in the average when compared to others by both S\&P and Moody's. Turkey has the lowest score in average among them according to both S\&P and Moody's gradings.

Table 1. Descriptive statistics of credit ratings of S\&P and Moody's

\begin{tabular}{lllll}
\hline & & South Africa (SA) & Hungary (HUN) & Turkey (TR) \\
\hline S\&P & Mean & 38.47368 & 36.54386 & 27.43860 \\
& Median & 40.00000 & 35.00000 & 27.00000 \\
& Std. & 2.450257 & 5.631766 & 3.712996 \\
& Min & 34.00000 & 28.00000 & 17.00000 \\
& Max & 41.00000 & 44.00000 & 32.00000 \\
\hline Moody's & Mean & 40.61404 & 40.33333 & 28.52632 \\
& Median & 41.00000 & 40.00000 & 27.00000 \\
& Std. & 2.265852 & 7.940253 & 4.272442 \\
& Min & 37.00000 & 31.00000 & 22.00000 \\
& Max & 44.00000 & 50.00000 & 35.00000 \\
\hline
\end{tabular}

In order to test the significance of different means, one-way ANOVA technique is utilized (Bluman, 2009). The null and alternative hypotheses of one-way ANOVA tests, and the test result are given in Table 2:

Table 2. One-way ANOVA test results

\begin{tabular}{lc}
\hline & S\&P \\
\hline Ho: $\mu_{H U N}=\mu_{S A}=\mu_{T R}$ & F- test statistic \\
Ha: At least one of the means is different & $115.314^{*}$ \\
\hline & Moody's \\
\hline Ho: $\mu_{H U N}=\mu_{S A}=\mu_{T R}$ & F- test statistic \\
Ha $=$ At least one of the means is different & $94.169^{*}$ \\
\hline
\end{tabular}

As seen from the one-way ANOVA test results, the average means of sovereign ratings of three countries are statistically different when compared the F-test value with the critical value of $\mathrm{F}_{2 ; 168}$ (3.04) at $5 \%$ significance level for both agencies. In order to compare the means of sovereign credit ratings of these countries in pairs, the independent $\mathrm{t}$-test is implemented. The null and alternative hypotheses of $\mathrm{t}$-test and their results are shown in Table 3:

Table 3. Independent t-test results

\begin{tabular}{lll}
\hline & $\begin{array}{l}\text { S\&P } \\
\mathrm{t} \text {-test statistics }\end{array}$ & $\begin{array}{l}\text { Moody's } \\
\mathrm{t} \text {-test statistics }\end{array}$ \\
\hline Ho: $\mu_{S A} \leq \mu_{H U N}$ & $2.372^{* *}$ (Unequal variances) & 0.257 (Unequal variances) \\
Ha $: \mu_{S A}>\mu_{H U N}$ & & \\
\hline Ho: $\mu_{S A} \leq \mu_{T R}$ & $18.728^{* *}$ (Unequal variances) & $18.87^{* *}$ (Unequal variances) \\
Ha: $\mu_{S A}>\mu_{T R}$ & \\
\hline Ho: $\mu_{H U N} \leq \mu_{T R}$ & $10.191^{* *}$ (Unequal variances) & $9.886^{* *}$ (Unequal variances) \\
Ha: $\mu_{H U N}>\mu_{T R}$ & & \\
\hline
\end{tabular}


B. Canbaloğlu - Ö. S. Alp - G. Küçükkocaoğlu 11/2 (2019) 1068-1078

According to t-test results, the critical value for all cases (to.025) approximately equals to 2.00 at $5 \%$ significance level, hence all the null hypotheses are rejected except for the Moody's ratings for the comparison of South Africa and Hungary. As a result, the S\&P ratings of South Africa is significantly higher than both sovereign ratings of Hungary and Turkey, and Turkey has the lowest rating average. As for Moody's case, the lowest sovereign ratings also belong to Turkey among the three countries.

The determinants of the sovereign credit rating are settled for this study according to the variables indicated in the study of Elkhoury (2008). Elkhoury (2008) evaluates the core studies (such as Cantor and Pecker, 1996; Haque et al., 1996) dealing with the determinants of sovereign credit ratings and maintains that the variables of GDP per capita, GDP growth rate, inflation rate, nongold foreign exchange reserves and past default history justify 90 percent of variability in the credit ratings for the both advanced and emerging countries. Therefore, the set of explanatory variables of credit ratings for these countries are determined as real GDP growth rate (RGDP_G), inflation rate (INF), current account balance (CAB) as a percentage of GDP, the ratio of foreign exchange reserves to imports (FXRES) and the ratio of external debt (EXDB) to GDP. ${ }^{2}$ The descriptive statistics of the explanatory variables are offered in Table 4.

Table 4. Descriptive statistics of the dependent variables

\begin{tabular}{lllll}
\hline & & South Africa & Hungary & Turkey \\
\hline RGDP_G & Mean & 2.846491 & 1.760526 & 5.825684 \\
& Median & 2.722000 & 2.594000 & 6.655000 \\
& Std. & 2.068299 & 3.055858 & 4.747827 \\
& Min & -2.301000 & -7.843000 & -14.37600 \\
& Max & 6.360000 & 5.288000 & 11.67800 \\
\hline INF & Mean & 5.722807 & 3.836842 & 9.648772 \\
& Median & 5.600000 & 4.100000 & 8.380000 \\
& Std. & 2.691522 & 2.558643 & 4.995207 \\
& Min & 0.400000 & -1.000000 & 4.350000 \\
& Max & 13.40000 & 8.600000 & 31.63000 \\
\hline CAB & Mean & -3.575965 & -2.131053 & -4.667544 \\
& Median & -3.780000 & -0.360000 & -4.640000 \\
& Std. & 1.839258 & 5.229777 & 1.862519 \\
& Min & -6.100000 & -10.89000 & -8.980000 \\
& Max & 0.900000 & 7.150000 & -0.260000 \\
\hline \multirow{2}{*}{ FXRES } & Mean & 37.40013 & 36.71633 & 43.23680 \\
& Median & 39.17754 & 33.80638 & 43.79668 \\
& Std. & 8.584852 & 10.67925 & 4.965749 \\
& Min & 18.34524 & 21.86299 & 31.90137 \\
& Max & 53.57718 & 55.51136 & 54.51433 \\
\hline EXDB & Mean & 29.17596 & 127.0177 & 40.80644 \\
& Median & 26.64405 & 132.2622 & 39.05956 \\
& Std. & 8.985773 & 0.373521 & 4.787434 \\
& Min & 17.62007 & 37.35215 & 34.15428 \\
& Max & 48.37368 & 192.1526 & 54.83220 \\
\hline
\end{tabular}

As remarked from Table 4, Turkey has the largest real GDP growth rate in average among the country set with $5.83 \%$. South Africa performs average $2.84 \%$ growth rate and the Hungary has the lowest level of real GDP growth with $1.76 \%$ in quarter period. As for inflation, the highest average inflation rate belongs to Turkey with $9.64 \%$, South Africa and Hungary follow Turkey with an average inflation rate of 5.72\% and $3.84 \%$, respectively. When it comes to the current account balance variable, Turkey has the largest current

\footnotetext{
2 As for default history variable, the data is checked from the database of history of sovereign defaults of Bank of Canada. However, there is no default history of South Africa, and this makes a zero vector for the default history for it. The inclusion of this variable for South Africa make no sense. In order to be able to compare the countries, same variables are included in the regression models.
} 
B. Canbaloğlu - Ö. S. Alp - G. Küçükkocaoğlu 11/2 (2019) 1068-1078

account deficit among these three. However, Hungary and South Africa also have current account deficits with closer ratios to Turkey's current account deficit rate in average. Turkey possesses the largest ratio of foreign exchange reserves to imports when compared to both Hungary and South Africa. In terms of external debt rate, Hungary has the largest external debt with a rate of $127 \%$, which indicates quite larger external debt use when compared to other two countries. Turkey and South Africa have external debt rate of $29 \%$ and $41 \%$ in average. All the economic variables are obtained from Bloomberg database.

In order to examine the influence of the selected variables on the sovereign credit ratings, the ordinary least square regression (OLS) is utilized as in the studies of Cantor and Pecker (1996) and Vernezza and Nielson (1996). The regression models are in Eq.1 and Eq.2, and the results are offered as in Table 5, Table 6 and Table 7 for South Africa, Hungary and Turkey, respectively.

$$
\begin{array}{cc}
S P_{t}=\beta_{0}+\beta_{1} R G D P_{-} G_{t}+\beta_{2} I N F_{t}+\beta_{3} C A B_{t}+\beta_{4} F X R E S_{t}+\beta_{5} E X D B_{t}+v_{t} & \text { Eq.1 } \\
M D Y_{t}=\beta_{0}+\beta_{1} R G D P_{-} G_{t}+\beta_{2} I N F_{t}+\beta_{3} C A B_{t}+\beta_{4} F X R E S_{t}+5 E X D B_{t}+v_{t} & \text { Eq. } 2
\end{array}
$$

Table 5. OLS regression test results of South Africa

\begin{tabular}{lll|ll}
\hline \multicolumn{5}{l}{ South Africa } \\
\cline { 2 - 5 } & \multicolumn{2}{l}{ S\&P } & Moody's & \\
\cline { 2 - 5 } & Coef. & t-test & Coef. & t-test \\
\hline Constant & 39.59887 & $30.90789^{*}$ & 39.92094 & $29.41292^{*}$ \\
RGDP_G & 0.099756 & 0.877934 & -0.10329 & -0.858114 \\
INF & 0.156682 & $2.363186^{* *}$ & 0.166364 & $2.368589^{* *}$ \\
CAB & -0.286536 & $-2.45301^{* *}$ & -0.09830 & -0.794432 \\
FXRES & 0.148458 & $5.52567^{*}$ & 0.20606 & $7.239859^{*}$ \\
EXDB & -0.304456 & $-10.4683^{*}$ & -0.274995 & $-8.925389^{*}$ \\
\hline$R^{2}$ & & 0.7577 & & 0.6820 \\
Adj. R ${ }^{2}$ & & 0.7339 & & 0.6508 \\
\hline
\end{tabular}

As observed, the economic growth does not have significant impact on both ratings of South Africa. The S\&P and Moody's ratings of South Africa are affected by the increasing inflation and foreign exchange reserves to imports ratio positively and significantly, while it is influenced by rising external debt ratio negatively and significantly. Furthermore, the deteroriations in current account deficit lead to increases in the S\&P and Moody's ratings of the country. The gradings of both rating agencies for South Africa seem not to be affected negatively by increasing inflation and worsening current account deficit, which is not expected. On the other hand, the ratings of the country increase with a rise in foreign exchange reserve ratio, and a fall in external debt ratio as expected. As for the explanatory power of regression model, $73.4 \%$ variation of the S\&P sovereign ratings and $65 \%$ variation of the Moody's ratings are explained by these factors.

\begin{tabular}{|c|c|c|c|c|}
\hline & \multicolumn{4}{|c|}{ Hungary } \\
\hline & \multicolumn{2}{|r|}{ S\&P } & \multicolumn{2}{|r|}{ Moody's } \\
\hline & Coef. & t-test & Coef. & t-test \\
\hline Constant & 44.09150 & $23.57627^{*}$ & 47.17679 & $17.19692^{*}$ \\
\hline RGDP_G & -0.117531 & -0.987871 & -0.245511 & -1.406764 \\
\hline INF & 0.465876 & $3.002039^{*}$ & 0.265687 & 1.167129 \\
\hline CAB & -0.454108 & $-4.492551^{*}$ & -0.995400 & $-6.713259^{*}$ \\
\hline FXRES & -0.027912 & -0.653478 & -0.059478 & -0.949271 \\
\hline EXDB & -0.071416 & $-4.194427^{*}$ & -0.058008 & $-2.322567^{* *}$ \\
\hline $\mathrm{R}^{2}$ & & 0.9017 & & 0.8936 \\
\hline Adj. $R^{2}$ & & 0.8921 & & 0.8832 \\
\hline
\end{tabular}

Table 6. OLS regression test result of Hungary

The credit ratings of both agencies for Hungary are not affected by the economic growth as noticed in South Africa case. The S\&P credit ratings of Hungary significantly rises as the inflation increases. The impact of inflation also seems positive on the Moody's ratings but it is found to be insignificant. The ratings of both agencies boost when the current account deficit exacerbates and the external debt increases in Hungary. It is remarkable that increasing inflation and worsening current account deficit cause increases in the credit 
B. Canbaloğlu - Ö. S. Alp - G. Küçükkocaoğlu 11/2 (2019) 1068-1078

ratings for Hungary. In essence, an increase in these variables are expected to make negative contribution to the sovereign credit ratings. On the other hand, the external debt is a significant variable that makes negative contribution of credit ratings of Hungary as anticipated. In addition, $89.2 \%$ variation of ratings of S\&P and the $88.3 \%$ of variation of Moody's ratings for Hungary are explained by these determinants.

Table 7. OLS regression test results of Turkey

\begin{tabular}{|c|c|c|c|c|}
\hline & \multicolumn{4}{|c|}{ Turkey } \\
\hline & \multicolumn{2}{|c|}{ S\&P } & \multicolumn{2}{|c|}{ Moody's } \\
\hline & Coef. & t-test & Coef. & t-test \\
\hline Constant & 13.83462 & $3.572622^{*}$ & -5.004963 & -0.934669 \\
\hline RGDP_G & 0.095145 & $1.682785^{* * * *}$ & -0.046281 & -0.591948 \\
\hline INF & -0.632556 & $-9.770843^{*}$ & -0.576411 & $-6.438758^{*}$ \\
\hline $\mathrm{CAB}$ & -0.877248 & $-4.600624^{*}$ & -1.575973 & $-5.976957^{*}$ \\
\hline FXRES & -0.012961 & -0.178869 & 0.048697 & 0.485981 \\
\hline EXDB & 0.382756 & $4.811220^{*}$ & 0.732755 & $6.660846^{*}$ \\
\hline $\mathrm{R}^{2}$ & \multicolumn{2}{|c|}{0.7723} & \multicolumn{2}{|c|}{0.6712} \\
\hline Adj. $R^{2}$ & \multicolumn{2}{|c|}{0.7500} & \multicolumn{2}{|c|}{0.6390} \\
\hline
\end{tabular}

Finally for Turkey's case, an increase in real GDP growth leads to an increase in S\&P grades of Turkey, as expected. On the other hand, Turkey is the only country that has a negative impact of rising inflation on its sovereign ratings of both agencies. A rise in the current account deficit leads to an increase in Turkey' credit grades of both the S\&P and Moody's as previously noted in Hungary and South Africa cases. Another contrasting point is that increasing external debt is not negatively evaluated by the both S\&P and Moody's for Turkey, which was not detected for Hungary and South Africa. These factors account for the $75 \%$ and $63.9 \%$ of variation in credit ratings of S\&P and Moody's for Turkey, respectively.

By constructing the OLS regression and regressing the credit ratings on the economic variables such as GDP growth, public debt to GDP ratio, current account, past default etc., Vernazza and Nielsen (2015) retrieve the "objective component" of the sovereign ratings models measured by the coefficient of determination -the Rsquared- (particularly adjusted $\mathrm{R}^{2}$ ). The part, which cannot be explained by the "objective component" is specified as the "subjective component" (i.e. residual part-the remaing after $\mathrm{R}^{2}$ ). The subjective part, which is designated for the factors influencing the sovereign credit ratings, cannot be controlled by the economic or measurable country-specific variables and represents the subjectivity (i.e. sort of bias) of these credit rating agencies about the sovereigns. Regarding Vernezza and Nielson (2015), the subjective component of each model for three countries is investigated. Hungary has adjusted- $R^{2}$ values of approximately $89 \%$ and $88 \%$ for S\&P and Moody's, respectively, which reflects the objective component part of sovereign credit ratings models. The remaining roughly $11-12 \%$ part of the variation in credit ratings is the subjective part of the models designed for Hungary. When it comes to South Africa, the adjusted $\mathrm{R}^{2}$ values are $73 \%$ and $65 \%$ for S\&P and Moody's models, respectively. The subjective component explains $27 \%$ of variation of S\&P model and accounts for the 35\% of variation of the Moody's model for South Africa. Finally for Turkey, the rougly $75 \%$ of variation in sovereign ratings of S\&P is explained by the objective component and the remaining $25 \%$ of variation in its S\&P ratings is represented by the subjective factor. In addition, $63 \%$ of variation in Moody's grades of Turkey is explained by the objective factors, whereas 37\% of variation in the Moody's graded consists of subjective component that cannot be controlled by the country-specific variables. All in all, Hungary is the country that is exposed to the least subjectivity by both rating agencies according to the evaluations based on coefficient of determination. On the other hand, South Africa and Turkey are exposed to closer amounts of bias by credit rating agencies and the subjectivity components of these countries are relatively higher when compared to Hungary. From the S\&P perspective, South Africa has the highest subjective component among the three, but Turkey is also biasedly evaluated as high as South Africa. On the other hand, Turkey is exposed to the highest subjectivity of Moody's agency according to the empirical results.

As a further analysis, the pooled regression with country dummies is also employed to examine the existence of country specific bias in terms of credit ratings. The credit ratings of both agencies are regressed 
B. Canbaloğlu - Ö. S. Alp - G. Küçükkocaoğlu 11/2 (2019) 1068-1078

on both economic variables and country dummies as in Eq. 3 and Eq.4, and the results are presented in Table 8.

$$
\begin{array}{ccc}
S P_{t} & =\beta_{1} R G D P_{-} G_{t}+\beta_{2} I N F_{t}+\beta_{3} C A B_{t}+\beta_{4} F X R E S_{t}+\beta_{5} E X D B_{t}+\beta_{6} S A_{-} D+\beta_{7} H U N_{-} D+\beta_{8} T R_{-} D+v_{t} & \text { Eq.3 } \\
M D Y_{t} & =\beta_{1} R G D P_{-} G_{t}+\beta_{2} I N F_{t}+\beta_{3} C A B_{t}+\beta_{4} F X R E S_{t}+\beta_{5} E X D B_{t}+\beta_{6} S A_{-} D+\beta_{7} H U N_{-} D+\beta_{8} T R_{-} D+v_{t} & \text { Eq.4 }
\end{array}
$$

\begin{tabular}{|c|c|c|c|c|}
\hline & \multicolumn{2}{|c|}{ S\&P } & \multicolumn{2}{|c|}{ Moody's } \\
\hline & Coef. & t-test & Coef. & t-test \\
\hline RGDP_G & .0256997 & 0.43 & -.1262398 & -1.64 \\
\hline INF & -.660346 & $-4.19^{*}$ & -.0808224 & -1.15 \\
\hline CAB & -.660346 & $-9.28^{*}$ & -.9675612 & $-10.43^{*}$ \\
\hline FXRES & -.0207935 & -0.67 & .0207305 & 0.611 \\
\hline EXDB & -.0607517 & $-4.44^{*}$ & -.0800045 & $-4.48^{*}$ \\
\hline SA_D & 39.88365 & $34.23^{*}$ & 39.53483 & $26.03^{*}$ \\
\hline HUN_D & 44.45615 & $28.08^{*}$ & 48.24271 & $23.37^{*}$ \\
\hline TR_D & 29.76704 & $20.94^{*}$ & 27.89383 & $15.06^{*}$ \\
\hline $\mathrm{R}^{2}$ & \multicolumn{2}{|c|}{0.9952} & \multicolumn{2}{|c|}{0.9930} \\
\hline Adj. $R^{2}$ & \multicolumn{2}{|c|}{0.9950} & \multicolumn{2}{|c|}{0.9926} \\
\hline
\end{tabular}

Table 8. Pooled regression test results with country dummies

There seems no significant impact of economic growth and foreign exchange reserves on the credit ratings of both agencies, while there exist significant impact of current account deficit and external debt ratio on ratings. The effect of inflation on the grading seems significant only in S\&P. As for the country dummies, irrespective of economic variables Hungary is assigned with the highest grade from both agencies, the South Africa follows it with the second highest constant coefficent. Finally, it is observed that Turkey receives the least grading from both agencies. The explanation powers of both models are quite high.

\section{Conclusion and Discussion}

This study mainly disentangles whether the ratings of South Africa, Hungary and Turkey, classified in the emerging market economies, are graded by S\&P and Moody's with a bias / subjectivity or not by also exploring the economic determinants of these countries' credit ratings over the period of 2002:Q4 - 2016:Q4. Though these countries are grouped under the emerging market economies and they do not have so distant macroeconomic indicators, the ratings of the countries may be exposed to subjectivity when they are evaluated by the CRAs. This may result from that the countries' economic and political ties with the advanced economies may overshade the objective part of CRAs' rating assessments (i.e. evaluation depending on the economic indicators).

Firstly, the factors such as real GDP growth, inflation, current account balance, foreign exchange reserve ratio and external debt, which are considered as main contributing factors of credit ratings do not offer clearcut findings for these countries. As for South Africa, a rise in its foreign exchange reserves increases its ratings, whereas an increase in its external debt ratio affects its ratings in a negative way, as anticipated. However, the rises in inflation and current account deficit do not cause any decrease in the grading of South Africa. Similarly, increases in inflation and current account deficit do not lead to any decrease in the scores of Hungary, only the decline in scores results from the increase in external debt of Hungary. For both Hungary and South Africa, the real GDP growth is not found as one of the most significant determinants of sovereign ratings as pointed out in the existing literature. On the other hand, real GDP growth and inflation are found as significant factors contributing to Turkey's credit ratings. An increase in economic growth and a rise in inflation lead to a rise and a decline in the scores of Turkey assigned by S\&P, respectively. In addition, an increase in current account deficit and external debt ratio also do not result in decline in Turkey's scores. Secondly, the subjectivity components of credit ratings retrieved from the regressions, indicate that Hungary is exposed to the least subjectivity when compared to others. However, the models of South Africa and Turkey involve higher and similar amount of bias according to their regression models, which implies that these two countries are not mainly rated by these economic indicators. The ratings against Turkey and South Africa may include different judgments and indicators other than economic ones. But when the scores of these countries from both agencies are compared, Turkey has lower rating scores 
B. Canbaloğlu - Ö. S. Alp - G. Küçükkocaoğlu 11/2 (2019) 1068-1078

when compared to South Africa. Finally, the pooled regression results also present similar findings about the country-specific subjectivity in the credit gradings for these countries. Regardless of economic factors, some countries have high grades initially. Hungary is graded with the highest score among three although its economic indicators are not superior than South Africa and Turkey. Similarly, South Africa is also judged with higher grades than Turkey despite the fact that there are no remarkable differences between economic indicators of these two countries. As a result, this study provides evidence that the gradings of CRAs can also include some subjectivity/bias for some emerging economies when evaluating them within the emerging country group. This can result from the countries' political and / or economic intense affairs with the powerful economies as observed in the case of South Africa and UK relations, and the Hungary's membership of EU.

All in all, the role and importance of CRAs in the financial markets cannot be discarded since their ratings are considered significantly in the international financial markets. In particular, the downgrades in ratings (i.e. downscaling a country's rating from investment grade to speculative grade) can cause overreactions in the financial markets, which, in turn, gives rise to a negative bias against these countries, and increases in their cost of borrowing and default spreads. In such a responsive financial environment, the CRAs should be more transparent and more informative about their rating methodologies and standardize the procedures for all country groups. Moreover, they should also aim to minimize the subjectivity in their evaluations, and provide fair capital allocations and investing opportunities, particularly for emerging economies.

\section{References}

Bluman, A.G. (2009). Elementary Statistics: A Step by Step Approach, New York, NY: McGraw Hill.

Cantor, R. and Packer. F. (1996). Determinants and Impact of Sovereign Credit Ratings. Federal Reserve Bank of New York Economic Policy Review, 2, 37-53.

Doluca, H. (2014), Home Country Bias in Sovereign Ratings? SSRN: https://ssrn.com/abstract=2397238 or http://dx.doi.org/10.2139/ssrn.2397238 (Date Accessed: 16 June 2018).

Elkhoury, M. (2008). Credit Developing Agencies and Their Potential Impact on Developing Countries, United Nations Conference On Trade and Development. Discussion Papers, 186.

European Union. (2018), Economic and monetary affairs, https://europa.eu/europeanunion/topics/economic-monetary-affairs en (Date Accessed: 7 July 2018).

Fuchs, A. and Gehring, K. (2017). The Home Bias in Sovereign Ratings, Journal of the European Economic Association, 15 (6), 1386 - 1423.

Gaillard, N. (2009). The Determinants of Moody's Sub-Sovereign Ratings, International Research Journal of Finance and Economics, 31, 194 - 209.

GOV.UK. (2012), Britain and South Africa: a 21st century partnership, https://www.gov.uk/government/speeches/britain-and-south-africa-a-21st-century-partnership (Date Accessed: 16 April 2018).

Haque, N., Kumar, M., Mark, N. and Mathieson, D. (1996). The economic content of indicators of developing country creditworthiness, IMF Staff Papers, 43, 688-724.

Hu, Y., Kiesel, R. and Perraudin, W. (2002). The estimation of transition matricesfor sovereign credit ratings. Journal of Banking \& Finance, 26, 1383 - 1406.

Iyengar, S. (2012). The Credit Rating Agencies - Are They Reliable? A Study of Sovereign Ratings, Vikalpa, $37(1), 69-82$.

Kabadayi, B. and Celik, A. A. (2015). Determinants of Sovereign Ratings in Emerging Countries: A Qualitative, Dependent Variable Panel Data Analysis, International Journal of Economics and Financial Issues, 5 (3), 656-662. 
B. Canbaloğlu - Ö. S. Alp - G. Küçükkocaoğlu 11/2 (2019) 1068-1078

Kucukksarac, D. and Duran, M. (2016). How Different are the Factors Affecting the Credit Ratings of Developed and Emerging Countries? Central Bank of Republic of Turkey Research Notes in Economics, 2016-09.

Larrain, G., Helmut, R. and Maltzan, J. (1997). Emerging Market Risk and Sovereign CreditRatings, OECD Development Centre Technical Paper, 124, April.

Luitel P., Vanpée, R. and Moor, L. (2016). Pernicious effects: How the credit rating agencies disadvantage emerging markets, Research in International Business and Finance, 38, 286-298.

Mellios, C. and Paget-Blanc, E. (2006). Which Factors Determine Sovereign Credit Ratings?, The European Journal of Finance, 12 (4), 361-377.

Moody's Investor Service. (2017), Rating Symbols and Definitions, https://www.moodys.com/researchdocumentcontentpage.aspx?docid=PBC 79004 (Date Accessed: 12 November 2018).

S\&P Global Ratings. (2016), S\&P Global Ratings Definitions. https://www.standardandpoors.com/en US/delegate/getPDF;jsessionid=005C648113C23F417F0597F7B FD95063?articleId=1824955\&type=COMMENTS\&subType=REGULATORY $\quad$ (Date Accessed: 12 November 2018).

Tennant, D. and Tracey, M. (2016). Sovereign Debt and Rating Agency Bias, United States: Palgrave Macmillan US.

US Securities and Exchange Comission (US SEC). (2004). Report on the Role and Function of Credit Rating Agencies in the Operation of the Securities Markets: As Required by Section 702(b) of the Sarbanes-Oxley Act of 2002, New York: W. S. Hein \& Co., Inc.

Vernazza, D. R. and Nielson, E. F. (2015). The Damaging Bias of Sovereign Ratings. Economic Notes by Banca Monte dei Paschi di Siena SpA, 44 (2), 361-407. 